\title{
POLITICAL REGIMES OF THE POST-SOVIET STATES OF THE CENTRAL ASIA AND CAUCASUS
}

\begin{abstract}
The subject of this research is the political regimes of the post-Soviet states of Central Asia and Caucasus. The author gives an in-depth analysis to the typology problems of the modern political regimes and the methodological aspects of measuring the regime dynamics. Special attention is given to the issue of operationalization of the proposed concepts and review of empirical data, which can objectively reflect the character of the political regimes. The author claims that the measurement of these two parameters: level of competition among the elites and the degree of influence of informal practices within the political process, represents the most relevant assessment of the regime forms of the post-Soviet states. A synthesis of two theoretical concepts is used in this article. It offers the typology of the political regimes, developed upon the electoral and neopatrimonial approaches. By combining the two basic variables (level of competition and the autonomy of the elites) six possible regime types are determined: atomized particularism, sultanism, neopatrimonial authoritarianism, neopatrimonial polyarchy, institutionalized authoritarianism and institutionalized polyarchy. For the offered criteria of the assessment of the regimes, the author formulates a method of operationalization using the data from the electoral statistics and indexing the levels of corruption. The regime dynamics of the post-Soviet Turkmenistan is presented in the article as a demonstration of the practical implementation of the developed typology.
\end{abstract}

Keywords: Political regime, typology, democracy, authoritarianism, political process, post-Soviet territory, neopatrimonialism, Central Asia, Caucasus, Turkmenistan.

T he two criteria that allow us to assess a form of a specific regime are: 1) the level of competition among the political actors in the race for the seat of authority; 2) the degree of the formal institutionalization of the government administration. They are based on the definition of the political regime as a fusion of the formal and informal rules that regulate the channels of access to the positions of authority and form the models of state governing.

In order to determine the first criterion, a classic electoral approach is used. According to the author's scale, this variable can have two meanings: high or low level of political competition. In this case this means the formal competition among the elites, which is reflected in the electoral results.

The degree of institutionalization of state governing can be expressed and evaluated through such empirically observed phenomenon as the degree of "autonomy among the elites". This concept is used in accordance with the theoretical positions of Anna Grzymala-Busse and Pauline Jones Luong, who were first to offer this criterion in their typology of the process of governmental structuring of the post-Soviet states [7]. According to their model, the index of the degree of the elites' autonomy is closely related to the level of formal institutionalization of the political process. When competition among the elites is formalized, they face a complex of restrictions. Such restrictions include not only constitutional and legislative norms, but also the inability to use the strategies of suppression and co-option of its contenders, considering that the strong and formal institutions exclude the politicization of bureaucracy, which is also regulated by the supremacy of law, and acts in accordance with the model of legal-rational behavior avoiding the clientelistic strategies.

The neopatrimonial type of governing creates the conditions of a limited, and not the ultimate freedom of autonomy of the elites. In the conditions of a neopatrimonial governing and defective functionality of the legislative norms, it is neither the program nor the ideological party that become the primary channel of access to the positions of authority, but patron-clientelistic networks. The competition between the politicians that are autonomous from the public is not for the electoral votes, but for the support of a patron, in whose network the elites want to co-opt in order to have access to the material resources. As a result, clientelistic parties are being developed, which do not have ideologies, but possess an administrative capital [8, p. 14]. It is these parties in the form of incumbent projects ("party of authority"), or oligarchic party clientele, along with informal institutions in form of patronal networks become the main channel of access to the positions of authority. Thus within a neopatrimonial environment the elites rid themselves from public control dependency, but being an integral part of the patron-clientelistic network they preserve the informal dependency upon their patrons.

The utmost patrimonial model of governing does elevate the level of autonomy of the elites to a maximum, but the absolute freedom in reality still has certain limitations. These limitations however, are reduced to a minimum and originate either from a despotic ruler, who utilizes highly personalized patrimonial governing practices, or from the local small groups that act as the clientele and have ties to the leaders.

Following the neopatrimonial paradigm, this work combines the concept "autonomy of the elites" with three possible idealtypical models of state governing. This allows us to highlight the three possible meanings of this variable:

1) Bureaucratic model. It is characterized by the low degree of autonomy of the elites, which represents a high level of institutionalization of governing and domination of the rational-legal practices of government administration in ideal-typical interpretation of Max Weber.

2) Neopatrimonial model. It is expressed in the medium level of elites' autonomy and presence of formal bureaucratic institutions 


\section{Право и политика $12(180) \cdot 2014$}

and informal patrimonial practices, based upon personal ties with the patron-clientelistic networks.

3) Patrimonial model. This represents the high autonomy of the elites and is defined by the predominance of informal, extremely personalized governing practices with minimal influence of constitutionalism and legal norms within administration.

By combining the two basic variable (level of competition and autonomy of the elites) six possible regime types can be defined and are offered in the form of a this table (refer to table 1).
The emergence of parallel patronal networks that have separated from the control of the dominant player characterizes the regime of patrimonial polyarchy. This leads to a more competitive electoral battle, often with an unpredictable electoral outcome. Unlike the institutional polyarchy, in this case under a high level of competition, the main political players are considered to be patrimonial networks, divided into clannish, sub ethnical, regional and oligarchic platforms. Clientelistic types of parties dominate. The regime of neopatrimonial polyarchy ultimately correlates with a hybrid (transitional) form, which combines elements of

Table 1.

Typology of political regimes

\begin{tabular}{|l|l|l|l|}
\hline & \multicolumn{3}{|c|}{ Degree of autonomy of the elites } \\
\hline Competition of the elites & $\begin{array}{l}\text { High } \\
\text { (Patrimonial) }\end{array}$ & Mild (Neopatrimonial) & $\begin{array}{l}\text { Low } \\
\text { (Bureaucratic) }\end{array}$ \\
\hline High & Atomized particularism & Neopatrimonial polyarchy & Institutional polyarchy \\
\hline Low & Sultanism & $\begin{array}{l}\text { Neopatrimonial } \\
\text { authoritarianism }\end{array}$ & Institutional authoritarianism \\
\hline
\end{tabular}

In the conditions of a patrimonial governing and depending on the level of competition of the elites, the regimes are divided into sultanistic regime and the regime of atomized particularism.

In the first instance the absence of formal institutions with a low competition among the elites, leads to the rise of a despot, whose authoritative powers are not restricted by any formal or informal boundaries. In the context of the post-Soviet political development such sultanistic regime has formed in Turkmenistan headed by President Saparmurat Niyazov. The situation of high competition among the elites coupled with the patrimonial institutionalized environment leads to the atomization of the elites, who receive the ultimate degree of autonomy, relying on their own resources and local patronal networks. Not complying with neither the capital, nor the competing elites they enter into a battle with each other using the model "war of all against all". This regime of atomized particularism practically means a situation of a civil war and a temporary disintegration of the statehood. The nature of this regime was most vividly demonstrated in Tajikistan during the 1992-1997 period of confrontation between the regional elites, when regional leaders and field commanders supported by their own forces and personal local patronal networks enter into a prolonged conflict with each other. However, Tajikistan is far from being the only case where a nation was able to accomplish a regime transformation through atomized particularism. In the shorter chronological periods this regime can also be seen within the Caucasus republics. Therefore, it can be concluded that highlighting this form of regime in the framework of analyzing the post-Soviet political processes is fairly reasonable and justifiable.

The neopatrimonial character of governing, depending on the degree of competition of the elites, leads to two possible types of regimes: neopatrimonial authoritarianism, or neopatrimonial polyarchy. With the low competition of the elites emerges the neopatrimonial authoritarianism, which signifies the presence of a dominating actor, who relies upon the patron-clientelistic networks and a monopoly on the material resources. democracy. However, a defective functioning of democratic institutions [3] does not allow classifying this regime model as a democracy; it seems more reasonable to attribute it to the authoritarianism category.

Finally, with the existence of strong formal institutions, the institutionalized authoritarianism or institutionalized polyarchy regime types are possible. In both cases the elites have minimal autonomy. However, in the conditions of a low level of competition the lack of autonomy of elites means that they do not adhere to the community, rather to the construct of the dominating party. This regime corresponds to the Soviet system of the Communist party monopoly and represents the starting point of transformation of all post-Soviet nations. The development of the institutionalization and legal rational bureaucracy under high level of competition of the elites gives birth to a regime in a form of the institutionalized polyarchy, which is the closest model by its parameters that within the framework of the electoral typologies is usually defined as an "electoral democracy". Out of all post-Soviet states this regime has been established only within the three Baltic countries.

In order to measure a regime it is necessary to choose the operationalization method that would allow precise recording of the meanings of two variables: the degree of competition of the elites and the level of their autonomy from the formally institutionalized restrictions.

Measuring the level of competition of the elites. As already stated above, within the political science a fairly common method of evaluating the regime types enables the use of the indexes from a number of research centers, scientific projects, or commercial organizations [4]. In particular, while measuring the level of competition of a regime many researches turn to the indexes of the quality of electoral process, which were developed as part of the projects such as Freedom House, Polity IV, the Economist magazine, Bertelsmann Institute and others. However, these indexes are usually compositional, in other words they contain not only the assessment of the "competition of the elites" variable, but 
also include a broader spectrum of factors of the electoral process. Therefore, for a more precise recording of the level of competition of the elites this work employs a different strategy.

Based on the positions of Tatu Vanhanen, who developed his famous index of democracy [14], the assessment of the level of competition among the elites will be conducted upon the official results of electoral outcomes. The greater percentage of votes for the oppositional candidates represents a marker that points to a substantial level of elite competition. The lower numbers of alternative voting allow us to come to an opposite conclusion. Although within the authoritarian regimes the electoral preferences of the voters are often distorted, the actual ability of the dominant bureaucracy to manipulate the electoral results speaks to its administrative power and capability to suppress splits among the elites if they are present. Thus, the official results of the electoral process at the exit poll provide the information of how much the incumbent controls the alternative patronal networks and is capable to prevent the breach of the outsiders into the public political space.

The electoral threshold that defines a low a level of elite competition would be considered a victory of the incumbent with a result of no less than $65 \%$ of the voter support. In evaluation of the legislature election this would mean that the ability of the incumbent to secure the control over $65 \%$ of the seats of the deputy corps speaks of a low elite competition. The incumbent can exercise this control through either the dominant representatives of the "ruling party" or through the conglomerate of the allied parties (cartel) and affiliated with the incumbent single mandate candidates, elected by the majority constituencies.

This is also the indicator of a low elite competition with the electoral outcome of presidential elections. Victory of a candidate with the voter support of no less than $65 \%$ signifies a low competition of the elites. An outcome of presidential election where the winner received less than $65 \%$ of the votes points to the existence of a high elite competition.

The definition of a regime structure as a neopatrimonial authoritarianism is acceptable only in the case where the incumbent is able to attain the electoral support of no less than $65 \%$ in both, the parliamentary and presidential elections. In the event that the incumbent is unable to secure that threshold even in one of the elections indicates the weakening of the regime consolidation and serves as the basis for attributing this regime to the type of one of the two possible variations of polyarchy.

Measuring the level of elites' autonomy. The second variable pointing to the correlation of the formal and informal institutions that limit the autonomy of the elites can be measured based on the data about the level of corruption. If corruption was viewed in its broader form as the "abuse of government power for personal gain" [2], then its factor can serve as a quite accurate assessment of the level of the spread of neopatrimonial relations within state governing.

In order to evaluate this factor ratings and indexes are used, which were compiled by the renowned research centers and finance institutions. The most widely used in various social research is the data from the Transparency International (TI) center, which produces annual publications of the ratings of countries arranged according to the Corruption Perception Index [13] developed by their researchers. Another index that is used just as often, is the Control of Corruption Index [12] offered by the specialist within the framework of the World Bank (WB) project.
In this work the data from the indexes of World Bank is used that include not only the index of corruption, but also other parameters of quality of state governing, which expands the possibilities of implementing the comparative methods of research and allows to demonstrate the character of government administration in a more volumetric measurement [9]. At the same time, TI' Corruption Perception Index is also used as a control of objectiveness of the data.

The WB index represents the range of measurement on a scale from -2.5 to 2.5 . The negative marks can serve as the indicator of a high level of corruption, where the positive point to a more favorable situation in this area [9].

The issue of measurement of such regime forms as sultanism and atomized particularism requires a special discussion within the framework of suggested typology. If the reviewed indexes are quite relevant in order to demarcate the regimes for neopatrimonial and institutionalized, then the edge between pure patrimonialism and neopatrimonial form of the quantitative methodology is uncertain.

As it was already stated above, sultanism is a regime, in which personal authority of the ruler does not have any limitations [11]. In post-Soviet political realities, elections are one of the important constraints of the head of the country. Namely the electoral processes, especially in a "crisis of the heritage" situation, can become an "Achilles' heel" of the authoritarianism, stimulate the consolidation of the counter elites and opposition, and be a trigger point for the mass mobilization. Due to this fact, the formal basis for attributing this regime to not just the neopatrimonial form, but to sultanism in particular can be the legal norm that secures the lifetime status of the head of state. Thus, the ruler practically frees himself from limitations such as elections, which results in a specific logic of functioning of an authoritarian regime. Not having the need to reconfirm his status as the dominating player, the ruler minimizes his dependency from society, as well as his subordinate clientele, turning into an absolute despot that would be very comparable to the classic models of unlimited monarchy. Therefore, existence of the norm that secures the lifetime status of a ruler would serve as the basis for classifying such regime as sultanism; absence of this norm would exclude the regime form this category.

Among post-Soviet countries of the Central Asia and Caucasus such norm enacted only in Turkmenistan in 1999 with regards to the President Saparmurat Niyazov, and continued until his death in 2006 [1, p. 468]. So the Turkmenistan regime in the period of 1999-2006 can be defined as sultanistic. Since 2007 when a new president took office, this norm has lost its power. Therefore, from 2007 Turkmenistan joined the ranks of neopatrimonial regime.

Atomizes particularism is also impossible to define using the quantitative procedures, but can be easily recorded based on the expert data. Understanding this regime as the maximal level of personalism alongside high elite competition, which leads to the weakening of the central authority and a confrontation between the key political players, this work captures the existence of this regime under the conditions of the open military conflict within a framework of separate polity. In other words the factors of the beginning and ending of a civil war or a limited local conflict represent fairly clear parameters, which allow defining the regime at a stage of atomized particularism and a period of its transition into another phase.

The regime of atomizes particularism among the reviewed nations is identified in three instances: 


\section{Право и политика 12 (180) • 2014}

1. Azerbaijan has undergone this regime in the period of confrontation between field commanders and the president of the country Abulfaz Elchibey (1992-1993).

2. Georgia went through the phase of atomized particularism during the period of confrontation between the field commanders and President Zviad Gamsakhurdia (1992).

3. Tajikistan was thrown into a civil war between regional elites. This event can also be attributed to the categories of atomized particularism.

As an example of defining the type of a regime based on the stated conceptual positions an assessment of a regime dynamics of the post-Soviet Turkmenistan is demonstrated below. plies to the new president of Turkmenistan, from 2007 until now the regime can be defined as the neopatrimonial authoritarianism. The quality indexes of the state governing reinforce the neopatrimonial character of this regime.

The last electoral cycle of 2012-2013 confirmed the stable low competition of the elites. During the presidential elections of 2012 the incumbent received $97.4 \%$ of the votes [6]. And during the parliamentary elections of 2013, although conducted for the first time on the multi-party basis, the ruling elite still retained their 100\% monopoly [5]. The regime sustains all the key signs of neopatrimonial authoritarianism.

The generalized data of codifying the regime dynamics of the post-Soviet Turkmenistan are demonstrated in the table 2.7.

Table 2.

Codification of the regime dynamics of the post-Soviet Turkmenistan

\begin{tabular}{|l|l|l|l|l|}
\hline Years & Electoral events & $\begin{array}{l}\text { Support of the } \\
\text { winner }\end{array}$ & Corruption index & Regime \\
\hline 1990 & $\begin{array}{l}\text { Parliamentary (The Supreme } \\
\text { Soviet) }\end{array}$ & $100 \%$ & No data & Institutionalized \\
authoritarianism
\end{tabular}

In Turkmenistan the opposition in the course of the reformation did not present a significant influence and the incumbent has effortlessly retained his authoritative positions. During the elections of the Supreme Soviet in 1990 the representatives of the Communist elites preserved their monopoly [10], while the First Secretary of the Republican Communist Party Saparmurat Niyazov was elected as the president receiving $98.3 \%$ of the electoral support. The regime took the form of the neopatrimonial authoritarianism. Future fluctuations within the regime were linked only to the fact of granting the president the status the lifetime ruler in 1999 [1, p. 468]. From that point and all the way until the death of Saparmurat Niyazov in 2006 this allows codifying the regime as sultanism. The crisis of the heritage was easily overcome by the elites preserving its integrity, and in 2007 the new candidate from among insiders was able to secure $89.2 \%$ of the votes during the presidential elections. The parliamentary elections have followed the same pattern, which on the one-party bases provided the ruling group with a $100 \%$ monopoly. Since the norm about the lifetime status of the ruler no longer ap-
Thus, the following positions represent the main conclusions of this research:

1. In order to solve the issue of measuring the dynamics of a regime this work offers the typology of the post-Soviet political regimes. The specificity of the examined instances in form of regimes of the post-Soviet states requires consideration of not only the electoral regime parameters, but also the analysis of the area of state governing, pertaining to such sphere as quality of bureaucratic administration. Therefore, the suggested classification is based on the synthesis of the electoral and neopatrimonial approaches, able to assess the quality and type of e regime founded upon the two-dimensional measurement.

2. Measurement of the regime dynamics of the post-Soviet states should be conducted upon two criteria: 1) level of competition among the political actors in a race for the seats of authority, and 2) degree of formal institutionalization of state governing and political process. 
DOI: $10.7256 / 1811-9018.2014 .12 .14014$

При цитировании этой статьи сноска на dоі обязательна

Трансформация правовых и политических систем

3. By connecting the two basic variables (level of competition and autonomy of the elites) six possible regime types are defined: atomized particularism, sultanism, neopatrimonial authoritarianism, neopatrimonial polyarchy, institutionalizes authoritarianism, and institutionalized polyarchy.
4. The difference of this classification of the regime types from other counterparts is linked to the consideration of the informal aspects of politics during the measuring of political regimes. The developed typology allows evaluating a regime from a special angle, capturing the degree of autonomy of the elites and the level of spreading of the informal practices of the regime functionality.

\section{Библиография:}

1. Dobronravin N. Turkmenistan : velikoe odinochestvo // SSSR posle raspada / red. O. L. Marganiya. SPb. : Ekonomicheskaya shkola, 2007. S. 455-476.

2. Lazarev E.A. Korruptsiya i politicheskaya stabil'nost' : institutsional'naya perspektiva // Politiya. 2011. № 1 (60). S. 50-68.

3. Merkel' V., Kruassan A. Formal'nye i neformal'nye instituty v defektnykh demokratiyakh // Polis. 2002. № 1. S. 6-17.

4. Mironyuk M.G., Timofeev I.N., Vaslavskii I.Ya. Universal'nye sravneniya s ispol'zovaniem kolichestvennykh metodov analiza (Obzor pretsedentov) // Polis. 2006. № 5. S. 39-57.

5. Podvedeny itogi vyborov // Turmenistan : zoltoi vek [Elektronnyi dokument]. URL : http://turkmenistan.gov.tm/?id=5528 (data obrashcheniya :25.01.2014).

6. TsIK Turkmenistana priznal Berdymukhamedova pobeditelem // Podrobnosti [Elektronnyi dokument]. URL : http://podrobnosti.ua/power/2012/02/16/820746.html (data obrashcheniya : 13.03.2013).

7. Grzymala-Busse A., Luong, P. Reconceptualizing the state : lessons from post-communism // Politics \& Society. 2002. Vol. 30. № 4. P. 529-544.

8. Hale H. Why Not Parties in Russia? Democracy, Federalism, and the State. Cambridge University Press, 2006. 275 p.

9. Kaufmann D., Kraay A., Mastruzzi M. The Worldwide Governance Indicators. Methodology and Analytical Issues. The World Bank Development Research Group Macroeconomics and Growth Team. Policy Research Working Paper. № 5430. 2010. 29 p.

10. Montgomery K., Remington T. Regime transition and the 1990 Soviet republican elections// Journal of Communist Studies and Transition Politics. 1994. Vol.10. № 1. P. 55-79.

11. Sultanistic Regimes / ed. by H. E. Chehabi and J. Linz. Baltimore and London : The Johns Hopkins Univ. Press, 1998. 284 p.

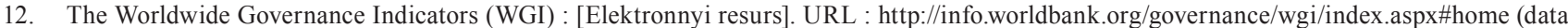
obrashcheniya : 13.04.2013).

13. Transparency International [Elektronnyi dokument]. URL : http://www.transparency.org/ (data obrashcheniya : 11.03.2013).

14. Vanhanen T. The Emergence Of Democracy : A Comparative Study Of 119 States, 1850-1979. (Commentationes scientiarum socialium). Helsinki : Societas Scientiarum Fennica, 1984. 168 p.

15. Shkel' S.N. Protsedurnye faktory ustoichivosti avtoritarnykh rezhimov: kontseptual'naya ramka analiza // Pravo i politika. - 2014. - 6. C. 799-806. DOI: 10.7256/1811-9018.2014.6.12192.

16. S. N. Shkel', N. E. Gareeva Sovremennye metodologicheskie podkhody i teoreticheskie modeli issledovaniya politiko-rezhimnykh transformatsii na postsovetskom prostranstve // Pravo i politika. - 2012. - 1. - C. 156-162

\section{References (transliterated):}

1. Dobronravin N. Turkmenistan : velikoe odinochestvo // SSSR posle raspada / red. O. L. Marganiya. SPb. : Ekonomicheskaya shkola, 2007. S. 455-476.

2. Lazarev E.A. Korruptsiya i politicheskaya stabil'nost' : institutsional'naya perspektiva // Politiya. 2011. № 1 (60). S. 50-68.

3. Merkel' V., Kruassan A. Formal'nye i neformal'nye instituty v defektnykh demokratiyakh // Polis. 2002. № 1. S. 6-17.

4. Mironyuk M.G., Timofeev I.N., Vaslavskii I.Ya. Universal'nye sravneniya s ispol'zovaniem kolichestvennykh metodov analiza (Obzor pretsedentov) // Polis. 2006. № 5. S. 39-57.

5. Podvedeny itogi vyborov // Turmenistan : zoltoi vek [Elektronnyi dokument]. URL : http://turkmenistan.gov.tm/?id=5528 (data obrashcheniya :25.01.2014).

6. Grzymala-Busse A., Luong, P. Reconceptualizing the state : lessons from post-communism // Politics \& Society. 2002. Vol. 30. № 4. P. 529-544.

7. 8. Hale H. Why Not Parties in Russia? Democracy, Federalism, and the State. Cambridge University Press, 2006. 275 p.

8. Kaufmann D., Kraay A., Mastruzzi M. The Worldwide Governance Indicators. Methodology and Analytical Issues. The World Bank Development Research Group Macroeconomics and Growth Team. Policy Research Working Paper. № 5430. 2010. 29 p.

9. Montgomery K., Remington T. Regime transition and the 1990 Soviet republican elections// Journal of Communist Studies and Transition Politics. 1994. Vol.10. № 1. P. 55-79.

10. Vanhanen T. The Emergence Of Democracy : A Comparative Study Of 119 States, 1850-1979. (Commentationes scientiarum socialium). Helsinki : Societas Scientiarum Fennica, 1984. 168 p.

11. Shkel' S.N. Protsedurnye faktory ustoichivosti avtoritarnykh rezhimov: kontseptual'naya ramka analiza // Pravo i politika. - 2014. - 6. C. 799-806. DOI: 10.7256/1811-9018.2014.6.12192.

12. S. N. Shkel', N. E. Gareeva Sovremennye metodologicheskie podkhody i teoreticheskie modeli issledovaniya politiko-rezhimnykh transformatsii na postsovetskom prostranstve // Pravo i politika. - 2012. - 1. - C. 156-162 